\title{
ETHNOMEDICINAL POTENTIAL OF SARCOSTEMMA ACIDUM IN DIFFERENT REGIONS IN INDIA
}

\author{
SANDEEP PANDEY* \\ Centre for Botany, School of Environmental Biology, Awadhesh Pratap Singh University, Rewa, Madhya Pradesh, India.
} Email: sandeep27pandey@rediffmail.com

Received: 22 January 2018, Revised and Accepted: 21 February 2018

\section{ABSTRACT}

Objective: The aim of this study is to collect and enumerate the uses of Sarcostemma acidum (Somlata) in the treatments of various diseases and to evaluate knowledgeable information on traditional practitioners among different communities in India.

Methods: This was an extensive survey of literature on ethnopharmacological uses of S. acidum in Indian system of traditional medicine (TM), and the collected information documented in tabular form.

Results: The collected literature reveals that the plant is used as TM by the indigenous community in states such as Madhya Pradesh, Gujarat, Telangana, Karnataka, Andhra Pradesh, Tamil Nadu, Rajasthan, Maharashtra, Uttaranchal, West Bengal, Uttar Pradesh, and Andaman and Nicobar Islands. These communities are using the whole plant in $29 \%$, stem $15 \%$, latex $24 \%$, roots $10 \%$, leaves $17 \%$, and flowers in $5 \%$ of cases for treating 40 different types of ailments important being ear ache, snake bite, rheumatism, dog bite, emetic, chronic ulcer, and bone fracture.

Conclusions: Due to insufficient knowledge, lack of information and overexploitation has made the plant species under threat. The present survey provides proper documentation of ethnomedicinal uses of the plant and provides a valuable source of information for traditional practitioners and researchers with a special emphasis on developing policies for conservation and sustainable use of this species.

Keywords: Traditional medicines, Sarcostemma acidum, Ethnomedicinal uses.

(C) 2018 The Authors. Published by Innovare Academic Sciences Pvt Ltd. This is an open access article under the CC BY license (http://creativecommons. org/licenses/by/4. 0/) DOI: http://dx.doi.org/10.22159/ajpcr.2018.v11i5.24887

\section{INTRODUCTION}

Traditional medicine (TM) also termed, complementary medicine, an important part of health care with a long history of use in health maintenance and in disease prevention and treatment, is widely used in most countries, and its use is increasing rapidly in other countries. There is a growing interest in TM extending beyond products as they are cost savings. Special focus should be paid to their best use, for health and protect users of these products, and also to promote practices and practitioners [1]. Today, the TMs provide health service to $80 \%$ of the world's population. In India, a total of 427 Ethnic Communities [2], majority of which still rely on the traditional system of medicine to treat various disorders and their daily needs [3-7], are practicing this age-old tradition. They have invaluable knowledge about the medicinal properties of plants growing in their vicinity and their various miscellaneous uses [8-12].

Sarcostemma acidum Wight. \& Arn. commonly known as "Somlata," is an important member of family Asclepiadaceae. According to mythological belief the plant was a source of "Soma" that was used to prepare a rejuvenating drink "Somras," although this belief is still debated by scholars [13]. The plant is a part of traditional medicine among aboriginal communities in India since time immemorial. The plant is known to exist mainly in warmer part of India and generally prefers dry or semi-dried rocky places with low rainfall, shade, and moisture conditions. The plant is a perennial jointed shrub, with fleshy glabrous twig having milky white latex (Fig. 1a). Leaves are opposite mainly reduced to scales (Fig. 1b) [14]; roots are brownish, and flowers actinomorphic, with pale green or white in colour. The plant is bitter, cooling, narcotic, acrid, emetic, and rejuvenating [15] containing carbohydrate terpenes, phytosterols, saponins, and lignin [16]. The plant possesses antimicrobial, anti-inflammatory, antifertility, anti-ulcer, anxiolytic, antipsychotic, and central nervous system inhibitory property [17-21].
Due to the diverse presence of the plant in Euro-Asian region and warmer part of India, unique medicinal properties, and uses by the Ethnic Communities in India [14], it becomes necessary to assess pharmacognostic details of the plant for evaluation and formulation of a suitable dosage of bioactive compounds for the preparation of effective drugs and their application in treating various diseases and sharing information with the rest of the world. Moreover, the documentation of indigenous knowledge on the use of plants helps in gathering information about the geographical distribution of the plant and to forward suggestions for its sustainable use and conservation and to preserve the unrecorded information [22] which may either be lost forever. Therefore, there is an urgent need to record this precious ethnomedicinal knowledge about the plant so that in future it could aid in drug discovery and development of affordable health care for poor and rural people. Keeping the aforesaid facts in view,

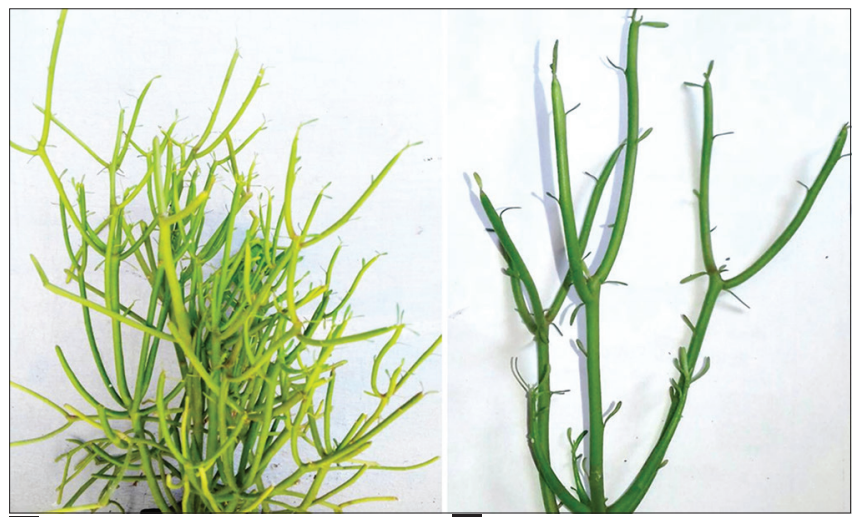

a the plant bearing opposite scale leaves 
the present study was made to record the use of $S$. acidum herbal preparations used by different indigenous communities in various regions of India.

\section{METHODS}

An extensive literature on ethnopharmacological uses of S. acidum in Indian system of TM was surveyed. The relevant literature sources were shown in table form, including the name of indigenous groups, locality, the ailment treated, the plant part used, and mode of preparations. The plant sample was also collected and identified from the study area in the Rewa district (24' 18 and 25' $12 \mathrm{~N}$ and 81' 2 and 82' $18 \mathrm{E}$ ), Madhya Pradesh. The information gathered was further discussed with subject experts to validate the claims about the plant material and its uses.

\section{RESULTS AND DISCUSSION}

Literature surveys on ethnomedicinal uses of $S$. acidum for treating various disorders by local or indigenous communities in different regions in India were reviewed. Ethnomedicinal uses of the plant to remedy various diseases are summarized in Table 1 with the indigenous group using them, region/state, disease treated, part(s) used, method, and sources. According to the research survey, the plant is used as TM by the indigenous community in treating ailments in the Indian states,, Madhya Pradesh, Gujarat, Telangana, Karnataka, Andhra Pradesh, Tamil Nadu, Rajasthan, Maharashtra, Uttaranchal, West Bengal, Uttar Pradesh, and Andaman and the Nicobar Islands. The collected information reveals that plant is an important aspect of TM among tribal communities, mainly in Andhra Pradesh, followed by Tamil Nadu and Telangana. As a matter of fact, it is interested to be noted that indigenous communities are using the whole plant in $29 \%$, stem $15 \%$, latex $24 \%$, roots $10 \%$, leaves $17 \%$, and flowers in $5 \%$ of cases for treating various diseases (Fig. 2).

Altogether, these communities are using the plant for treating 40 unique types of ailments, namely, an earache $(8 \%)$, snake bite $(7 \%)$, rheumatism, dog bite and emetic ( $6 \%$ each), bone fracture (5\%) mental disease, lactation, allergic rhinitis, and chronic ulcer ( $4 \%$ each), cold, cooling effect, lotion, swelling, infection, inflammation, whooping cough and bronchitis, burning micturition, cow skin parasites, hemorrhagic septicemia, and wound and burns (2\% each), and sinusitis and allergy, cough, asthma, epilepsy, cataract, gastric problem, rejuvenation, ocular infection, boils, skin disease, hypodermis disease, dipsia, viral infection, hydrophobia, insecticides, psychopathy, scabies, cow lactation, and antifertility (1\% each) (Fig. 3).

It is important to note that the indigenous communities of a different geographical region have their own mode of the use of plant parts to treat an ailment. The tribal community of Mandla, Bhopal, and Malwa region in Madhya Pradesh uses whole plant infusion or root twice a day for treating asthma [23], whereas in Dhinodhar hill Nakhatrana taluka, Kutch Gujarat, only the plant decoction is consumed for treating this disorder [24]. In Mandla, Bhopal, and Malwa region of Madhya Pradesh, the juice of the whole plant and roots is used as a remedy for cold [23], whereas in Sriharikota, Andhra Pradesh, the stem juice is used to treat cold [28]. The whole plant part is used to remedy inflammation and infection in Mandla, Bhopal, and the Malwa region of Madhya Pradesh [23], and in Walayar Valley, the Western Ghats, Tamil Nadu, only leaves are used as ailment to treat the disease [29]. Knickers tribes of Kalkulam Taluk, Tamil Nadu, use gently warm soft stem juice, while the Ethnic Communities of Krishna district, Andhra Pradesh, use leaf juice [34], in Purulia, West Bengal, dry powder decoction of the whole plant [35], and in Rayalaseema, Andhra Pradesh, plant root [36] as an ear drops for treating earache. Tribal communities in Barmer, Rajasthan, use the whole plant [22] and Yerukala tribes from Warangal, Telangana, applies latex [38] on joints to treat rheumatism, arthritis, and joint pain.

To treat snake bites, the rural people in Thar, Rajasthan, uses the extract of root, stem, and neem bark [32], the local community in Uttaranchal

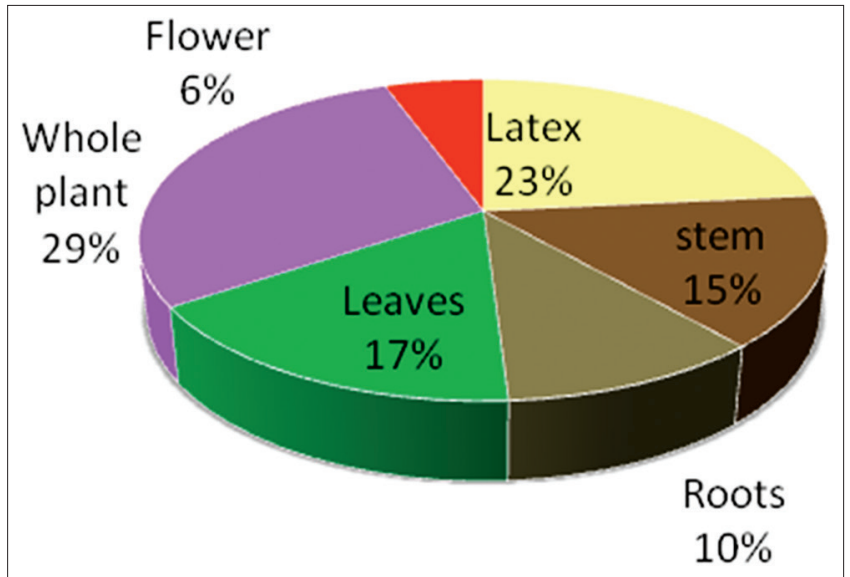

Fig. 2: The percentage of different plant parts used in treating ailments

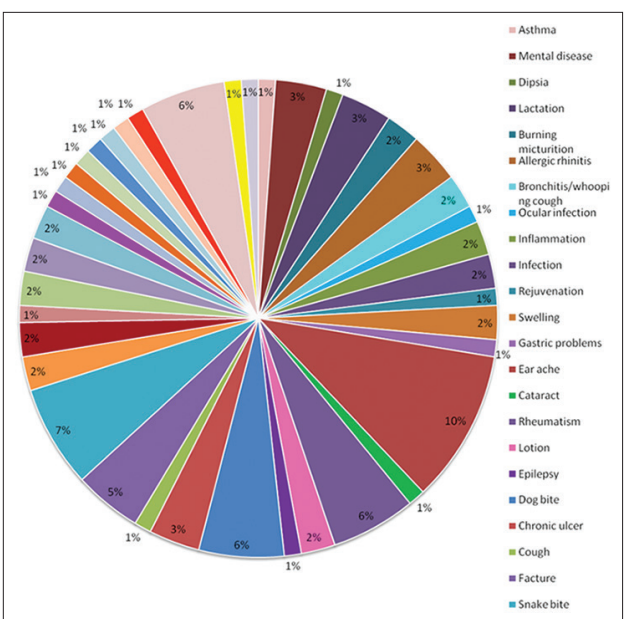

Fig. 3: Various ailments cured using Sarcostemma acidum plant

uses leaves, latex, and flower [39], and rural tribes of Madurai use plant root and neem bark [9]. The dog bite is cured using leaf powder and mustard oil by local tribes in Madurai, Tamil Nadu [9], mixture of root, stem extract, and neem bark is used by rural people in Thar, Rajasthan [32], and mixture of stem extract, Cynodon dactylon grass, and turmeric are applied on the bitten area for 2 weeks by Ethnic Community in Krishna, Andhra Pradesh [34], for treating this disorder. In Thoppampatti, Dindigul, Tamil Nadu, entire plant is consumed orally [46], Bhongir, Nalgonda, Telangana, latex is used [25], and in Madurai, Tamil Nadu, stem and root extract [9] are administered for emetic diseases. The local community in Sonbhadra, Uttar Pradesh, uses the whole plant [48], whereas in Uttaranchal, leaves, latex, and flower [39] are used in curing bone fracture. In case of wounds and burns, the tribes of Prakasam district apply latex externally [50], and on the contrary, fresh leaves are chewed with rock salt for the same disorder in the Eastern Ghats, Andhra Pradesh [51]. For sinusitis and allergy, the tribes of Paderu, Vishakhapatnam, Andhra Pradesh, utilize the whole plant [45], whereas Kani tribes in Keeriparai, Kanyakumari, Tamil Nadu, use roots and leaves to cure the disorder [10]. Local people in Dhinodhar hill, Nakhatrana Taluka, Kutch, Gujarat, applies latex to the cattles to kill skin parasites [24], but the tribes of Andaman and Nicobar Islands use all parts either administered orally or applied externally to eliminate the bugs [54]. The local community in Purulia, West Bengal, uses latex [35], and North Warangal and South Nalgonda, Telangana, use bark [40], whereas in Mandla, Bhopal, and Malwa, Madhya Pradesh, the infusion of crushed plant and water is taken twice a day [23] to increase lactation in women. 
Table 1: Ethnomedicinal uses of $S$, acidum for various ailments in India

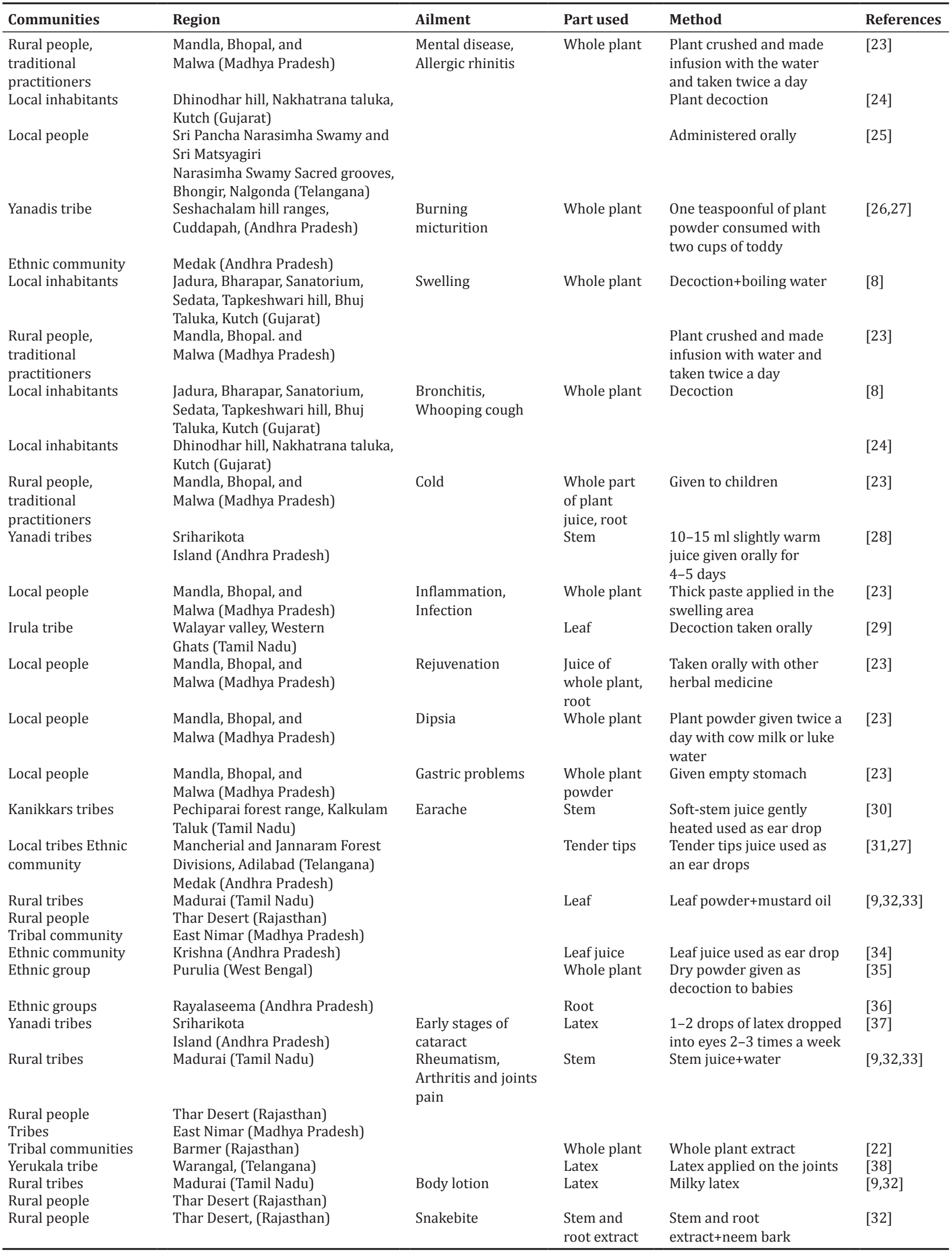


Table 1: (Continued)

\begin{tabular}{|c|c|c|c|c|c|}
\hline Communities & Region & Ailment & Part used & Method & References \\
\hline Local people & Uttaranchal & & $\begin{array}{l}\text { Leaves, latex, } \\
\text { flower }\end{array}$ & $\mathrm{N} / \mathrm{A}$ & [39] \\
\hline Local community & $\begin{array}{l}\text { Northern Warangal and Southern } \\
\text { Nalgonda (Telangana) }\end{array}$ & & Bark & $\begin{array}{l}\text { Aqueous extract of stem } \\
\text { bark }\end{array}$ & {$[40]$} \\
\hline Rural tribes & Madurai (Tamil Nadu) & & Root & Root+neem bark & {$[9,27,41]$} \\
\hline Ethnic community & Medak (Andhra Pradesh) & & & & \\
\hline Koyas tribe & Warangal (Telangana) & & & & \\
\hline Rural tribes & Madurai (Tamil Nadu) & Dog bite & Leaf & $\begin{array}{l}\text { Dry leaf powder+mustard } \\
\text { oil }\end{array}$ & [9] \\
\hline Rural people & Thar Desert (Rajasthan) & & $\begin{array}{l}\text { Stem and } \\
\text { root extract }\end{array}$ & $\begin{array}{l}\text { Stem and root } \\
\text { extract+neem bark }\end{array}$ & {$[32]$} \\
\hline $\begin{array}{l}\text { Yanadi tribe, } \\
\text { Local community }\end{array}$ & $\begin{array}{l}\text { Chittoor (Andhra Pradesh) } \\
\text { Jogimatti forest, }\end{array}$ & & Root & Root infusion & {$[42,43]$} \\
\hline Ethnic community & $\begin{array}{l}\text { Chitradurga (Karnataka) } \\
\text { Krishna (Andhra Pradesh) }\end{array}$ & & Stem extract & $\begin{array}{l}\text { Stem extract+C. dactylon } \\
\text { grass+turmeric applied on } \\
\text { bitten area for } 2 \text { weeks }\end{array}$ & {$[34]$} \\
\hline Rural tribes & Madurai (Tamil Nadu) & Chronic ulcer & Latex & $\begin{array}{l}3 \text { drops of latex+honey } \\
\text { thrice a day }\end{array}$ & {$[9,25,44]$} \\
\hline Sacred grooves & Bhongir, Nalgonda (Telangana) & & & & \\
\hline Paliyan tribes & $\begin{array}{l}\text { Sirumalai hills, Eastern } \\
\text { Ghats (Tamil Nadu) }\end{array}$ & & & & \\
\hline Rural tribes & Madurai (Tamil Nadu) & Emetic & $\begin{array}{l}\text { Stem and } \\
\text { root }\end{array}$ & Stem and root extract & [9] \\
\hline Local community & $\begin{array}{l}\text { Jogimatti forest, } \\
\text { Chitradurga (Karnataka) }\end{array}$ & & Stem & Dried stems & {$[43,45]$} \\
\hline Paderu tribes & Visakhapatnam (Andhra Pradesh) & & & & \\
\hline Village peoples & $\begin{array}{l}\text { Thoppampatti Dindigul (Tamil } \\
\text { Nadu) }\end{array}$ & & Whole plant & Oral and raw & {$[46]$} \\
\hline Sacred grooves & Bhongir, Nalgonda (Telangana) & & Latex & N/A & [25] \\
\hline Local community & $\begin{array}{l}\text { Northern Warangal and Southern } \\
\text { Nalgonda (Telangana) }\end{array}$ & Bone facture & $\begin{array}{l}\text { Stem } \\
\text { Whole plant }\end{array}$ & Stem paste & $\begin{array}{l}{[40,47]} \\
{[48]}\end{array}$ \\
\hline $\begin{array}{l}\text { Tribes local } \\
\text { community }\end{array}$ & $\begin{array}{l}\text { Harda (Madhya Pradesh) } \\
\text { Sonbhadra (Uttar Pradesh) }\end{array}$ & & & & \\
\hline Local people & Uttaranchal & & $\begin{array}{l}\text { Leaves, latex, } \\
\text { flower }\end{array}$ & $\mathrm{N} / \mathrm{A}$ & [39] \\
\hline Yanadis tribes & Cuddapah (Andhra Pradesh) & $\begin{array}{l}\text { Epilepsy/Hysteric } \\
\text { fits }\end{array}$ & Stem & $\begin{array}{l}\text { Water solution of pulpy } \\
\text { mesocarp given as nasal } \\
\text { drops }\end{array}$ & [49] \\
\hline Tribes & Prakasam (Andhra Pradesh) & Wounds/Burns & Latex & Applied externally & [50] \\
\hline Ethnic group & Eastern Ghats (Andhra Pradesh) & & Leaf & $\begin{array}{l}20-25 \text { fresh leaves chewed } \\
\text { with } 3-4 \text { pieces of rock salt } \\
\text { once per day for } 5 \text { days }\end{array}$ & [51] \\
\hline Local people & Uttaranchal & Boils & $\begin{array}{l}\text { Leaves, latex, } \\
\text { flower }\end{array}$ & $\mathrm{N} / \mathrm{A}$ & [39] \\
\hline Chenchus tribe & $\begin{array}{l}\text { Nallamalais } \\
\text { forest (Andhra Pradesh) }\end{array}$ & Ocular infections & Leaf sap & Used as eye drop & {$[52]$} \\
\hline Irula tribe & $\begin{array}{l}\text { Walayar valley, Western } \\
\text { Ghats (Tamil Nadu) }\end{array}$ & Cough & Leaf & Decoction taken orally & [29] \\
\hline Local people, tribes & Nagpur (Maharastra) & Cooling effect & Stem & Applied orally & [53] \\
\hline Tribes & $\begin{array}{l}\text { Paderu, } \\
\text { Visakhapatnam (Andhra Pradesh) }\end{array}$ & Sinusitis/allergy & Whole plant & Whole plant & {$[45]$} \\
\hline Kani tribes & $\begin{array}{l}\text { Keeriparai Kanyakumari (Tamil } \\
\text { Nadu) }\end{array}$ & & $\begin{array}{l}\text { Roots and } \\
\text { leaves }\end{array}$ & $\mathrm{N} / \mathrm{A}$ & {$[10]$} \\
\hline Tribes & Andaman and Nicobar Islands & Cow lactation, & Whole plant & $\begin{array}{l}\text { All parts are administered } \\
\text { orally or applied externally }\end{array}$ & {$[54]$} \\
\hline Local inhabitants & $\begin{array}{l}\text { Dhinodhar hill, Nakhatrana taluka, } \\
\text { Kutch (Gujarat) }\end{array}$ & $\begin{array}{l}\text { Cattle skin } \\
\text { parasites (ticks, } \\
\text { mites, twine etc.) }\end{array}$ & Latex & Applied externally & [24] \\
\hline Tribes & Andaman and Nicobar islands & & Whole plant & $\begin{array}{l}\text { All parts are administered } \\
\text { orally or applied externally }\end{array}$ & [54] \\
\hline Tribes & $\begin{array}{l}\text { Rapur, Chitvel, Eastern } \\
\text { Ghats (Andhra Pradesh) }\end{array}$ & Scabies & Latex & $\begin{array}{l}\text { Latex applied externally } \\
\text { for } 1 \text { week }\end{array}$ & {$[11]$} \\
\hline Local people & Uttaranchal & Antifertility & $\begin{array}{l}\text { Leaves, } \\
\text { Latex, flower }\end{array}$ & $\mathrm{N} / \mathrm{A}$ & [39] \\
\hline Tribal community & $\begin{array}{l}\text { Kurnool, Prakasam, Guntur, } \\
\text { Nallamalais (Andhra Pradesh) }\end{array}$ & Skin disease & Latex & $\mathrm{N} / \mathrm{A}$ & {$[55]$} \\
\hline
\end{tabular}


Table 1: (Continued)

\begin{tabular}{|c|c|c|c|c|c|}
\hline Communities & Region & Ailment & Part used & Method & References \\
\hline Tribal community & $\begin{array}{l}\text { Kurnool, Prakasam, Guntur, } \\
\text { Nallamalais (Andhra Pradesh) }\end{array}$ & Asthma & Latex & $\mathrm{N} / \mathrm{A}$ & {$[55]$} \\
\hline Local tribes & Anantapur (Andhra Pradesh) & $\begin{array}{l}\text { Hemorrhagic } \\
\text { septicemia in cattle }\end{array}$ & Stem & $\begin{array}{l}\text { Stem paste+pepper } 50 \\
\text { g+goat milk. } 100 \mathrm{ml} \text { given } \\
\text { orally for } 5-6 \text { days }\end{array}$ & {$[56,57]$} \\
\hline Kadugolla tribes & Tumkur (Karnataka) & & & & \\
\hline Village peoples & $\begin{array}{l}\text { Thoppampatti, Dindigul } \\
\text { (Tamil Nadu) }\end{array}$ & $\begin{array}{l}\text { Viral infection, } \\
\text { hydrophobia, } \\
\text { insecticidal, } \\
\text { psychopathy }\end{array}$ & Whole plant & Oral and raw & [46] \\
\hline Rural tribes & Madurai (Tamil Nadu) & $\begin{array}{l}\text { Hypodermis } \\
\text { diseases }\end{array}$ & $\begin{array}{l}\text { Stem and } \\
\text { root }\end{array}$ & Stem and root extract & [9] \\
\hline Ethnic group & Purulia (West Bengal) & Lactation & Latex & $\mathrm{N} / \mathrm{A}$ & {$[35]$} \\
\hline Local community & $\begin{array}{l}\text { Northern Warangal and Southern } \\
\text { Nalgonda, (Telangana) }\end{array}$ & & Bark & $\mathrm{N} / \mathrm{A}$ & {$[40]$} \\
\hline $\begin{array}{l}\text { Rural people, } \\
\text { tradionalpractitioners }\end{array}$ & $\begin{array}{l}\text { Mandla, Bhopal. and } \\
\text { Malwa (Madhya Pradesh) }\end{array}$ & & Whole plant & $\begin{array}{l}\text { Plant crushed and made } \\
\text { infusion with the water and } \\
\text { taken twice a day }\end{array}$ & {$[23]$} \\
\hline
\end{tabular}

N/A-not available. S. acidum

Moreover, there are the reports of using the similar methodology to cure ailments by the different tribal community in different regions in India. Yanadis tribe of Cuddapah, Andhra Pradesh [26], and Ethnic Community in Medak, Andhra Pradesh [27], use whole plants in burning micturition. To cure swelling, the local people consumes decoction of the whole plant with water in Tapkeshwari hill, Bhuj Taluka, Kutch, Gujarat [8], and Mandla, Bhopal, and Malwa region, Madhya Pradesh [23]. The tribe of Tapkeshwari hill, Bhuj Taluka [8], and Dhinodhar hill, Nakhatrana taluka [24], Kutch, Gujarat, uses a plant decoction to remedy bronchitis and whooping cough. The local tribes of Mancherial and Jannaram Forest Divisions, Adilabad, Telangana [31] and Medak, Andhra Pradesh [27], use tender tips juice, and Madurai, Tamil Nadu [9], Thar desert, Rajasthan [32] and East Nimar, Madhya Pradesh [33], use leaf powder and mustard oil, as an ear drop for treating an earache. The native tribes of Madurai, Tamil Nadu [9], Thar, Rajasthan [32], and East Nimar, Madhya Pradesh [33], use stem juice and water in a similar fashion to treat rheumatism, arthritis, and joint pain.

The milky latex of the plant is used as a lotion by the tribal community of both regions Madurai, Tamil Nadu [9], and Thar Desert, Rajasthan [32]. To cure snakebite, the rural tribes of Madurai, Tamil Nadu [9], Medak, Andhra Pradesh [27], and the Koyas tribe of Warangal, Telangana [41], use Somlata plant root and neem tree bark for the ailment. Plant root infusions are a common mode of administration among Yanadi tribes, Chittoor, Andhra Pradesh [42], and local people of Jogimatti forest, Chitradurga, Karnataka [43], for treating dog bites. The treatment of chronic ulcer by consuming latex with honey is a common mode of administration among tribal communities of Madurai, Tamil Nadu [9], Paliyan tribes, Sirumalai hills, Eastern Ghats, Tamil Nadu [44], and Bhongir Nalgonda, Telangana [25]. The tribes of Paderu Visakhapatnam, Andhra Pradesh [45], and the local community of Jogimatti forest, Chitradurga, Karnataka [43], use stem for emetic disorders. The application of stem paste on the fractured bone is the common methods adopted by tribal community of Harda, Madhya Pradesh [47], and North and South Nalgonda, Telangana [40]. The local tribes of Anantapur, Andhra Pradesh [56], and Kadugolla tribes from Tumkur, Karnataka [57], have a similar mode of treating hemorrhagic septicemia in cattle using a mixture of stem paste, pepper, and goat milk and given orally to the cattle for 5-6 days.

As far the mode of preparation is concerned, most of the medicines are prepared from plant parts only without using any other ingredient. However, the aqueous solution (20 preparations), neem tree bark (three preparations), mustard oil (two preparations), toddy, cow milk, C. dactylon, turmeric, honey, rock salt, pepper, and goat milk (one preparation each) are used in addition along with the plant/parts, as per the prescribed dose most probably either to enhance or to neutralize unpleasant taste of the plant for easy consumption.

\section{CONCLUSION}

The present study provided medicinal knowledge of the various uses of $S$. acidum (Somlata) by different communities in India. The present study provided medicinal knowledge of the various uses of $S$. acidum (Somlata) by different communities in India. The study helps in documentation and substantiates in securing knowledge of the curative application of the plant. The ethnopharmacognostic information of the plant would be useful for further scientific studies. As the plant is categorized under threatened vulnerable species, there is an urgent need to frame a long-term strategy for the involvement of government organizations, traditional and all concerned communities to explore therapeutic potential, along with applying conservation strategies of plant species.

\section{CONFLICT OF INTEREST}

The authors have declared that no conflict of interest.

\section{REFERENCES}

1. WHO. Traditional Medicine Strategy: 2014-2023. Geneva: World Health Organization; 2013

2. Jeyaprakash K, Lego YJ, Payum T, Rathinavel S, Jayakumar K. Diversity of medicinal plants used by adi community in and around area of D' Ering wildlife sanctuary, Arunachal Pradesh, India. Wirel Sens Netw 2017;65:135-59.

3. Kumar S, Pandey S. An ethnobotanical study of local plants and their medicinal importance in Tons river area, Dehradun, Uttarakhand. Indian J Trop Biodiv 2015;23:227-31.

4. Pandey S, Shukla A, Pandey S, Pandey A. An overview of resurrecting herb 'Sanjeevani' (Selaginella bryopteris) and its pharmacological and ethnomedicinal uses. J Pharm Innov 2017;6:11-4.

5. Pandey S. Phytochemical constituents, pharmacological and traditional uses of Ocimum gratissimum $\mathrm{L}$ in tropics. Indo Am J Pharm Sci 2017;4:4234-42.

6. Pandey S, Singh SK, Kumar N, Manjhi R. Antiviral, antiprotozoal, antimalarial and insecticidal activities of Ocimum gratissimum L. Asian J Pharm Res Dev 2017;5:1-9.

7. Himshikha, Gupta RC, Singhal VK, Kumar R. Ethnomedicinal notes and chromosomal status of some selected herbs from Parvati Valley, Kullu District, Himachal Pradesh. Int J Pharm Pharma Sci 2017;9:191-6.

8. Patel YS, Joshi EP, Joshi PN. Ethnobotanical Study of Tapkeshwari Hill, Bhuj, Kachchh, India. Life Sci Leafl 2010;2:22-31.

9. Boomibalagan P, Eswaran S, Rathinavel S. Traditional uses of 
medicinal plants of asclepiadaceae by rural people in Madurai district, Tamil Nadu, India. Int J Bot 2013;9:133-9.

10. Ida CJ, Arul AA. Ethnobotanical study of kani tribesin keeriparai of Kanyakumari district, South India. Int Educ Res J 2016;2:49-52.

11. Basha SK, Priydarsini AI. Ethnobotanical study on rapur-chitvelghat, Eastern Ghats, Andhra Pradesh. Int J Eng Res Tech 2017;6:69-72.

12. Pandey S. Antibacterial and antifungal activities of Ocimum gratissimum L. Int J Pharm Pharma Sci 2017;9:26-31

13. Shah NC. The mystery and botanical identity of soma plant: An appraisal. Herbal Tech Industry 2011;8:19-28.

14. Pandey S, Shukla A, Pandey S, Pandey A. Morphology, chemical composition and therapeutic potential of Somlata (Sarcostemma acidum Wight. \&Arn.). Pharma Sci Monit 2017;8:54-60.

15. Warrier PK, Nambiar VP, Ramankutty C. Indian Medicinal Plants-A Compendium of 500 Species. Vol. 5. Chennai, India: Orient Longman Private Limited.; 2002.

16. Dave BK, Dhirawat R, Kumawat M. Pharmacognostical study of a medicinal plant of India - Sarcostemma acidum. Int J Pharm Phytochem Res 2014;6:690-7.

17. Mallam A, Angothu S, Gurajala S, Khuddus GA. Antimicrobial activity of Sarcostemma acidum Voigt (Apocynaceae) stem. Int J Bio Pharm Res 2012;3:752-7.

18. Gupta S, Kohli S, Dwivedi S. In-vitro anti-inflammatory activity of Sarcostemma acidum Wight. \&Arn. Indian herb by human red blood cell membrane stabilization method. Int J Pharm Teach Pract 2011;2:184-8.

19. Venma PK, Sharma A, Mathur A, Sharma P, Gupta RS, Joshi SC, et al. Effect of Sarcostemma acidum stem extract on spermatogenesis in male albino rats. Asian J Androl 2002;4:43-7.

20. Gulshan M, Chandrasekhar GN, Kumar BV, Ramarao N. Anti-ulcer activity of ethanolic Sarcostemma acidum stem extract. Int Res J Pharm 2017;8:91-4

21. Ittiyavirah SP, Rahees T. Evaluation of psychopharmacological activity of ethyl acetate extracts of Sarcostemma acidum (Roxb).voigt. J Phytopharm 2013;2:1-7.

22. Kapoor BB, Kumar S. Ethnomedicinal plants of Barmer district, Rajasthan used in herbal and folk remedies. Indian J Pharm Biol Res 2013;1:61-6.

23. Gupta S, Kohli S. Folklore uses of an endangered ethnomedicinal herb of India Sarcostemma acidum. (Somlata). formavita. Formerly Nat Prod Lett 2010;24:206-21.

24. Patel Y, Patel RM, Mahato AK, Joshi PN. Status and diversity of ethnomedicinal plants of Dhinodhar Hill, Kachchh district, Gujarat. Int J Plant Anim Environ Sci 2013;3:265-73.

25. Rao SS. Ethnobotanical study of medicinal plants of sri pancha narasimha swamy and sri matsyagiri narasimha swamy. J Med Plant Stud 2015;3:37-42

26. Reddy CS, Reddy KN, Murthy EN, Raju VS. Traditional medicinal plants in Seshachalam hills, Andhra Pradesh. Ind J Med Plnt Res 2009;3:408-12

27. Reddy KN, Trimurthulu G, Reddy CS. Medicinal plants used by ethnic people of Medak district, Andhra Pradesh, India. Indian J Tradit Knowl 2010;9:184-90.

28. Kumar RB, Suryanarayana B. Ethnomedicinal recipes for respiratory and bronchial diseases from tribals of Sriharikota Island, Andhra Pradesh. Ethnobot Leafl 2008;12:896-911.

29. Venkatachalapathi A, Tamilselvi SS, Paulsamy S. Ethnobotanical knowledge of Irula tribal community of Walayar Valley, Southern Western Ghats, India. Int J Rec Adv Multidis Res 2016;3:1379-92.

30. Shalini CB, Pillai SC, MohanVR. Ethnomedicinal plants used by the Kanikkars of Southern Western Ghats. Int J Pharm Sci Rev Res 2014;28:101-7.

31. Krishna NR, Saidulu C, Kistamma S. Ethnomedicinal uses of some plant studies Mancherial and Jannaram reserve forest division of Adilabad district, Telangana State. Ind J Sci Inno Res 2014;3:342-51.

32. Arora S, Kumar G, Saini M, Meena S. Ethnobotanical survey of the most threatened medicinally important asclepiads of Indian Thar desert. Int J Res Sci Innov 2015;3:51-5.

33. Ray S, Sheikh M, Mishra S. Ethnomedicinal plants used by tribals of East Nimar region, Madhya Pradesh. India J Tradit Knowl
2011;10:367-71

34. Reddy KN, Trimurthulu G, ReddySC. Plants used by ethnic people of Krishna district, Andhra Pradesh, India. India J Tradit Knowl 2010;9:313-7.

35. Dey A, De JN. Traditional use of medicinal plants in pediatric and maternal care practiced by the ethnic groups of Purulia district, West Bengal, India. Int J Med Arom Pl 2011;1:189-94.

36. Rao DM, Rao B, Gudivada S. Ethno-medico-botanical studies From Rayalaseema region of Southern Eastern Ghats, Andhra Pradesh, India. Ethnobot Leafl 2006;10:198-207.

37. Kumar RB, Suryanarayana B. Ethnomedicinal recipes for ophthalmic and ENT problems and allied diseases from Tribals of Sriharikota Island, Andhra Pradesh. Res J Pharma Bio Che Sci 2014;5:853-71.

38. Prabhakar G, Kamalakar P. Ethnobotanical formulations for chronic disorders by Yerukala tribe of Warangal District, Telangana. Ind J Appl Res 2014;4:36-40.

39. Adhikari BS, Babu MM, Saklani PL, Rawat GS. Distribution, use pattern and prospects for conservation of medicinal Shrubs in Uttaranchal State, India. J Mount Sci 2007:4:155-80.

40. Sreeramulu N, Suthari S, Ragan A, Raju VS. Ethno-botanico-medicine for common human ailments in Nalgonda and Warangal districts of Telangana, Andhra Pradesh, India. Annals Pl Sci 2013;2:220-9.

41. Suthari S, Raju V. Antidote Botanicals for Snake Bites from Koyas of Warangal District, Telangana. Ind J Her Spi Med Pl 2016;22:57-68

42. Vedavathy S, Sudhakar A, Mrdula V. Tribal medicinal plants of Chittoor. Anc Sci Life 1997;16:307-31.

43. Hiremath VT, Vijaykumar MM, Taranath TC. Survey on ethnomedicinal plants of jogimatti forest Chitradurga District, Karnataka, India. Environ We Int J Sci Tech 2010;5:223-33.

44. Karuppusamy S. Medicinal plants used by Paliyan tribes of Sirumalai hills of Southern. Ind Nat Prod Rad 2007;6:436-42.

45. Padal SB, Murty PP, Rao DS, Venkaiah M. Ethnomedicinal plants from paderu division of Visakhapatnam district, A.P, India. J Phytol 2010;2:70-91

46. Sivasankari B, Anandharaj M, Gunasekaran P. An ethnobotanical study of indigenous knowledge on medicinal plants used by the village peoples of Thoppampatti, Dindigul district, Tamilnadu, India. J Ethnopharm 2014;153:408-23.

47. Sainkhediya J, Ray S. Studies on the threatened ethnomedicinal plants used by Tribals of Harda District of M.P., India. Int J Sci Res 2014;3:2590-93.

48. Singh KK. Ethnomedicinal plants diversity in Sonbhadra district of southern Uttar Pradesh, India-utilization and conservation. In: Ethnobiology in Human Welfare, $4^{\text {th }}$ International Congress of Ethnobiology, Lucknow, Uttar Pradesh, India, 17-21 November, 1994. p. 83.

49. Reddy RV, Lakshmi NV, Raju RR. Traditional phytotherapy for epilepsy, fits and hysteria by Yanadis of Cuddapah district, a.p. Anc Sci Life 2000;19:92-5.

50. Mohan RK, Murthy PV. Plants used in traditional medicine by Tribals of Prakasam district, Andhra pradesh. Anc Sci Life 1992;11:176-81.

51. Reddy KN, Reddy CS, Trimurthulu G. Ethnobotanical survey on respiratory disorders in eastern Ghats of Andhra Pradesh, India. Ethnobot Leafl 2006;10:139-48.

52. Venkata RK, Reddy GT, Raju RR. Herbal remedies for eye infections used by the Tribals of Nallamala forests, Andhra Pradesh. India J Tradit Knowl 2010;9:765-7.

53. Shrirame AM, Gogle DP. Survey on ethnobotanical plants used for wound healing: Nagpur region. In: International journal of life sciences (SplIss A2), Natcon biodiversity conservation. Role of microbes in Sustain. Environ Mgmt 2014;10:62-4.

54. Ghosh A. Survey of ethno-medicinal climbing plants in Andaman and Nicobar Islands, India. Int J Pharm Life Sci 2014;5:3671-77.

55. Saheb TS. A study on medicinal climbers of Nallamalais, Andhra Pradesh. Int J Multidis Res Dev 2014;1:172-6.

56. Reddy KN, Raju RR. Plants in ethnoveterinary Practices in Anantapur district, Andhra Pradesh. J Econ Taxon Bot 1999;23:347-58.

57. Lakshmana SK. Herbal veterinary medicines from Kadugolla tribes of Tumkur district, Karnataka State. Int Res J Pharm Pl Sci 2013;1:93-105. 